\title{
The effect of a rachitogenic factor on calcium metabolism in chicks
}

\author{
By M. E. COATES, G. F. HARRISON AND E. S. HOLDSWORTH* \\ National Institute for Research in Dairying, \\ Shinfield, Reading, England
}

(Received 3 August 1960)

Raw pig's liver has been shown by Coates $\&$ Harrison (1957) to have rachitogenic properties for chicks. The rachitogenic activity was heat-labile and water soluble, but attempts to isolate and characterize the responsible factor have so far been unsuccessful. Meanwhile the studies reported here were undertaken to throw some light on its mode of action. Rachitogenic activity might depend on an interference with either the absorption of calcium or its deposition in bone; both these possibilities were investigated.

\section{EXPERIMENTAL AND RESULTS}

The management of the birds, determination of $\mathrm{Ca}$, counting methods and surgical procedures were as described in a previous paper (Coates \& Holdsworth, 196r).

\section{Preparation of rachitogenic factor}

Fresh pig's liver was homogenized in a Waring Blendor, spread on stainless-steel trays and dried in a current of air at $40^{\circ}$. It was milled finely and extracted with a mixture of 2 parts light petroleum (b.p. $40^{\circ}-60^{\circ}$ ), 2 parts diethyl ether and I part absolute ethanol. This extraction procedure has been shown to remove any vitamin $D_{3}$ present in the liver, leaving most of the rachitogenic activity in the residue. The extracted liver powder was spread on trays and allowed to dry at room temperature.

The dried extracted liver powder was added to the Olsson rachitogenic diet at the expense of whole diet, to provide the equivalent of $20 \mathrm{~g}$ fresh liver in $100 \mathrm{~g}$ diet (usually about $6 \%$ of the dried product). This quantity counteracts the antirachitic effect of about 3 i.u. vitamin $D_{3}$ (Coates \& Harrison, 1957).

\section{Determination of bone ash}

The birds were killed by breaking their necks; the left tibia was then removed from each and cleaned of soft tissue by scraping with a scalpel. The bones were defatted by extraction in a Soxhlet apparatus for $24 \mathrm{~h}$ with ethanol and with diethyl ether for a further $24 \mathrm{~h}$. They were dried in a desiccator, weighed and incinerated at about $700^{\circ}$. The resulting ash was weighed, the weight of ash being then expressed as a percentage of the weight of the defatted bone. For determination of ${ }^{45} \mathrm{Ca}$, the ash was dissolved

* Present address: Biochemistry Department, University of Adelaide, South Australia. 
in conc. $\mathrm{HCl}$ diluted $\mathrm{I}: \mathrm{I}$, any debris being removed by centrifuging. The calcium oxalate precipitated from a portion of the solution by adding $4 \%$ ammonium-oxalate solution was washed once with hot ammonia solution ( 1 part ammonia of sp.gr. 0.88 to 99 parts water), dried in a desiccator and spread on $25 \mathrm{~mm}$ diameter metal planchets, and the activity was counted at infinite thickness.

\section{Effect of rachitogenic factor on uptake of Ca from the duodenum}

Two experiments were done by the duodenal-loop technique on groups of chicks that had received the basal diet alone or with 23 i.u. vitamin $D_{3} / \mathrm{ro0} g$ or with a supplement of dried extracted liver equivalent to $20 \mathrm{~g}$ raw liver $/ \mathrm{ro0} \mathrm{g}$ diet. In the

\section{Table I. Effect of vitamin $D_{3}$ and a rachitogenic factor on absorption of calcium from duodenal loops in 4-week-old chicks}

\begin{tabular}{|c|c|c|c|c|}
\hline Supplement/roo g diet & $\begin{array}{c}\text { T.M.T.* } \\
\text { (mm) }\end{array}$ & $\begin{array}{c}\text { Ca absorbed } \\
\text { (mg) }\end{array}$ & $\begin{array}{c}\text { Bone ash } \\
(\%)\end{array}$ & $\begin{array}{c}\text { Activity in } \\
\text { bone ash } \\
\text { (counts/min) }\end{array}$ \\
\hline None & $\begin{array}{l}2 \cdot 125 \\
2 \cdot 5 \\
2 \cdot 5\end{array}$ & $\begin{array}{l}0.82 \\
0.82 \\
I \cdot 10\end{array}$ & $\begin{array}{l}34 \cdot 8 \\
35 \cdot 1 \\
35 \cdot 3\end{array}$ & $\begin{array}{l}529 \\
818 \\
992\end{array}$ \\
\hline Mean & $2 \cdot 375$ & 0.91 & $35 \cdot 1$ & 780 \\
\hline 23 i.u. vitamin $D_{3}$ & $\begin{array}{l}0.875 \\
1.0 \\
0.875\end{array}$ & $\begin{array}{l}2 \cdot 85 \\
1 \cdot 67 \\
2 \cdot 11\end{array}$ & $\begin{array}{l}46 \cdot 1 \\
43 \cdot 3 \\
43 \cdot 9\end{array}$ & $\begin{array}{r}958 \\
724 \\
1076\end{array}$ \\
\hline Mean & 0.917 & $2 \cdot 21$ & $44 \% 4$ & 919 \\
\hline Dried liver $(\equiv 20 \mathrm{~g}$ raw $)$ & $\begin{array}{l}2 \cdot 875 \\
2 \cdot 625 \\
3 \cdot 5\end{array}$ & $\begin{array}{l}0.49 \\
0.58 \\
0.61\end{array}$ & $\begin{array}{l}33 \cdot 6 \\
32 \cdot 4 \\
32 \cdot 7\end{array}$ & $\begin{array}{l}190 \\
613 \\
847\end{array}$ \\
\hline Mean & $3 \cdot 0$ & 0.56 & 32.9 & $55^{\circ}$ \\
\hline
\end{tabular}

first experiment the chicks had been on these treatments from I day old to 4 weeks and three birds were used from each. Calcium chloride containing $4 \mathrm{mg}$ labelled $\mathrm{Ca}$ was placed in duodenal loops and allowed to remain for $2 \mathrm{~h}$. At intervals during this time samples of blood were taken, and the radioactivity of the plasma was determined. At the end of the experiment the duodenal loops were removed and ashed, and the residual $\mathrm{Ca}$ was determined by the titration method. At the same time one tibia from each chick was removed for determination of radioactivity and bone ash. The values for all samples are presented in Table $I$, and the plasma radioactivity is plotted in Fig. $\mathrm{x}$. The birds given vitamin $\mathrm{D}_{3}$ absorbed a significantly greater amount $(P<0.0 \mathrm{I})$ of $\mathrm{Ca}$ than did those given the unsupplemented diet. The chicks that had received a supplement of dried liver were more rachitic than those on the basal diet, as indicated by the tarso-metatarsal distances and percentages of bone ash. They appeared to absorb even less $\mathrm{Ca}$ than the negative controls, but the difference was not statistically 
significant. The different effects of these three treatments on absorption of $\mathrm{Ca}$ from duodenal loops were reflected in the levels of radioactivity found in plasma and tibias.

In a second experiment, chicks were given the basal diet with or without 5 i.u. vitamin $D_{3} /$ roo g up to the age of 4 weeks. Four birds from each group were then given a supplement of dried liver ( $\equiv 20 \mathrm{~g}$ raw liver $/ \mathrm{r} 00 \mathrm{~g}$ diet $)$ for a further 5 days, when their uptake of $\mathrm{Ca}$ from duodenal loops was compared with that of four similar birds from each group that had received no liver supplement. Three chicks that had

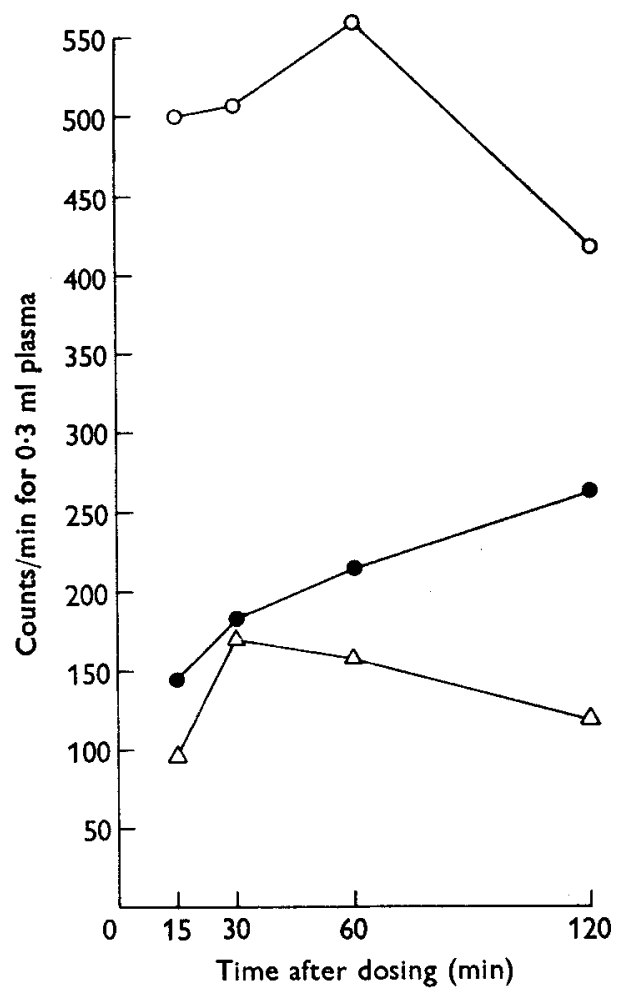

Fig. I. Levels of ${ }^{45} \mathrm{Ca}$ in plasma of normal and rachitic chicks given ${ }^{45} \mathrm{CaCl}_{2}$ placed in duodenal loops. Each point is the mean value for groups of three birds. $\mathrm{O}-\mathrm{O}$, basal diet +23 i.u. vitamin $\mathrm{D}_{3} / \mathrm{ro0} \mathrm{g} ;-$, basal diet; $\triangle-\triangle$, basal diet + dried liver ( $\equiv 20 \mathrm{~g} \mathrm{raw} / \mathrm{ro0} \mathrm{g}$ ).

received an optimal quantity of vitamin $\mathrm{D}_{3}$ from hatching were also included. The results are given in Table 2; as expected, the birds given vitamin $\mathrm{D}_{3}$ absorbed significantly $(P<0.0 \mathrm{r})$ more $\mathrm{Ca}$ than any of the rest. Although the apparent differences between the other four treatments did not reach statistical significance, there was a strong indication that the liver supplement had interfered with the ability of the duodenum to absorb $\mathrm{Ca}$, in both presence and absence of vitamin $\mathrm{D}_{3}$.

\section{Effect of the rachitogenic factor on deposition of ${ }^{45} \mathrm{Ca}$ in bone}

The disappearance from plasma of injected ${ }^{45} \mathrm{Ca}$ and its deposition in bone was compared in groups of chicks given the Olsson diet with or without vitamin $\mathrm{D}_{3}$ or rachitogenic factor. Calcium chloride containing $\mathrm{I} \mathrm{mg}$ labelled $\mathrm{Ca}$ in $0.25 \mathrm{ml}$ solution 
i52 M. E. Coates, G. F. Harrison ANd E. S. Holdsworth I96I

was given intravenously into the jugular vein of each bird, and blood samples were taken from the wing vein at intervals after injection. The birds were then killed, and one tibia was removed and ashed. Two of the experiments lasted for $2 \mathrm{~h}$ and one for

Table 2. Effect of supplements of dried pig's liver on absorption of calcium from duodenal loops of 4-week-old chicks

( $4 \mathrm{mg} \mathrm{Ca}$ as ${ }^{45} \mathrm{Ca}$-labelled $\mathrm{CaCl}_{2}$ were placed in washed-out duodenal loops, and the residual ${ }^{45} \mathrm{Ca}$ was determined after $2 \mathrm{~h}$. Each value is for one chick)

Supplement/roo g diet

During 4 weeks

None

23 i.u. vitamin $\mathrm{D}_{3}$
During last 5 days

None

Dried liver ( $\equiv 20 \mathrm{~g}$ raw liver)

5 i.u. vitamin $D_{3}$

5 i.u. vitamin $D_{3}$ and dried liver ( $\equiv 20 \mathrm{~g}$ raw liver)

23 i.u. vitamin $D_{3}$
Ca absorbed (mg)

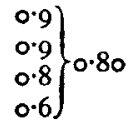

$\left.\begin{array}{l}0.9 \\ 0.6 \\ 0.4 \\ 0.6\end{array}\right\} 0.63$

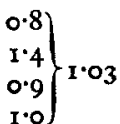

$\left.\begin{array}{l}1.0 \\ 0.8 \\ 1.0 \\ 0.7\end{array}\right\} 0.88$

$\left.\begin{array}{l}I \cdot 3 \\ I \cdot 9 \\ I \cdot 7\end{array}\right\} I \cdot 63$

Table 3. Mean values for the effect of vitamin $D_{3}$ or a rachitogenic factor on the deposition of injected ${ }^{45} \mathrm{Ca}$ in the tibias of 4-week-old chicks

(I $\mathrm{mg}^{45} \mathrm{CaCl}_{2}(0.5 \mu \mathrm{c}$ ) was injected into the jugular vein of the birds and blood samples were taken from the wings. Birds were killed after either $30 \mathrm{~min}$ or $2 \mathrm{~h}$, and the tibias were taken for bone ash and radioactivity measurements. The activity of the calcium oxalate from the bone ash was counted at infinite thickness)

\begin{tabular}{|c|c|c|c|c|c|c|}
\hline $\begin{array}{l}\text { Supplement/ } \\
\text { too g diet }\end{array}$ & $\begin{array}{c}\text { Time of } \\
\text { expt }\end{array}$ & $\begin{array}{l}\text { No. of } \\
\text { birds per } \\
\text { group }\end{array}$ & $\begin{array}{l}\text { Bone } \\
\text { ash } \\
(\%)\end{array}$ & $\begin{array}{c}\text { Wt of Ca } \\
\text { oxalate } \\
\text { (g) }\end{array}$ & $\begin{array}{c}\text { Activity of } \\
\text { Ca oxalate } \\
\text { (counts } / \mathrm{min} \text { ) }\end{array}$ & $\begin{array}{c}\text { Counts } / \mathrm{min} \\
\times \text { wt of } \\
\text { Ca oxalate }\end{array}$ \\
\hline $\begin{array}{l}23 \text { i.u. } D_{3} \\
\text { None } \\
\text { Dried liver }(\equiv 20 \mathrm{~g} \\
\text { raw liver })\end{array}$ & $\begin{array}{l}2 \mathrm{~h} \\
2 \mathrm{~h} \\
2 \mathrm{~h}\end{array}$ & $\begin{array}{l}4 \\
4 \\
4\end{array}$ & $\begin{array}{l}43 \cdot 8 \\
35 \cdot 0 \\
33 \cdot 3\end{array}$ & $\begin{array}{l}0.577 \\
0.398 \\
0.359\end{array}$ & $\begin{array}{l}494 \\
843 \\
867\end{array}$ & $\begin{array}{l}285 \\
336 \\
311\end{array}$ \\
\hline $\begin{array}{l}23 \text { i.u. } D_{3} \\
\text { None } \\
\text { Dried liver ( } \equiv 20 \mathrm{~g} \\
\text { raw liver })\end{array}$ & $\begin{array}{l}2 \mathrm{~h} \\
2 \mathrm{~h} \\
2 \mathrm{~h}\end{array}$ & $\begin{array}{l}3 \\
3 \\
3\end{array}$ & $\begin{array}{l}46 \cdot 5 \\
37 \cdot 0 \\
36 \cdot 0\end{array}$ & $\begin{array}{l}0.517 \\
0.367 \\
0.338\end{array}$ & $\begin{array}{l}358 \\
568 \\
6 \times 5\end{array}$ & $\begin{array}{l}r 89 \\
206 \\
207\end{array}$ \\
\hline $\begin{array}{l}23 \text { i.u. } \mathrm{D}_{3} \\
\text { None } \\
\text { Dried liver ( } \equiv 20 \mathrm{~g} \\
\text { raw liver) }\end{array}$ & $\begin{array}{l}30 \mathrm{~min} \\
30 \mathrm{~min} \\
30 \mathrm{~min}\end{array}$ & $\begin{array}{l}3 \\
3 \\
3\end{array}$ & $\begin{array}{l}45^{\circ} \cdot 5 \\
37 \cdot 5 \\
34 \cdot 7\end{array}$ & $\begin{array}{l}0.470 \\
0.349 \\
0.350\end{array}$ & $\begin{array}{l}340 \\
521 \\
697\end{array}$ & $\begin{array}{l}160 \\
184 \\
243\end{array}$ \\
\hline
\end{tabular}


$30 \mathrm{~min}$. The levels of radioactivity found in the plasma are plotted in Fig. 2; values referring to its appearance in bone are given in Table 3.

As expected, in all experiments the percentage bone ash of the birds given the rachitogenic factor was lower, and that of the chicks given vitamin $\mathrm{D}_{3}$ was considerably higher, than in the corresponding groups receiving only the basal diet. The radioactivity in the bones of the birds given vitamin $\mathrm{D}_{3}$ was little more than half tha in the other two groups. However, direct comparison of the counts/min in samples from each experimental group is valueless, since the birds that had received vitamin $D_{3}$ were heavier and consequently had much larger bones than those given either of the other two treatments. On multiplying the counts/min at infinite thickness of each sample by the total weight of calcium oxalate from the tibia, an arbitrary value is obtained that seems to us to offer a more valid basis for comparison. Inspection of

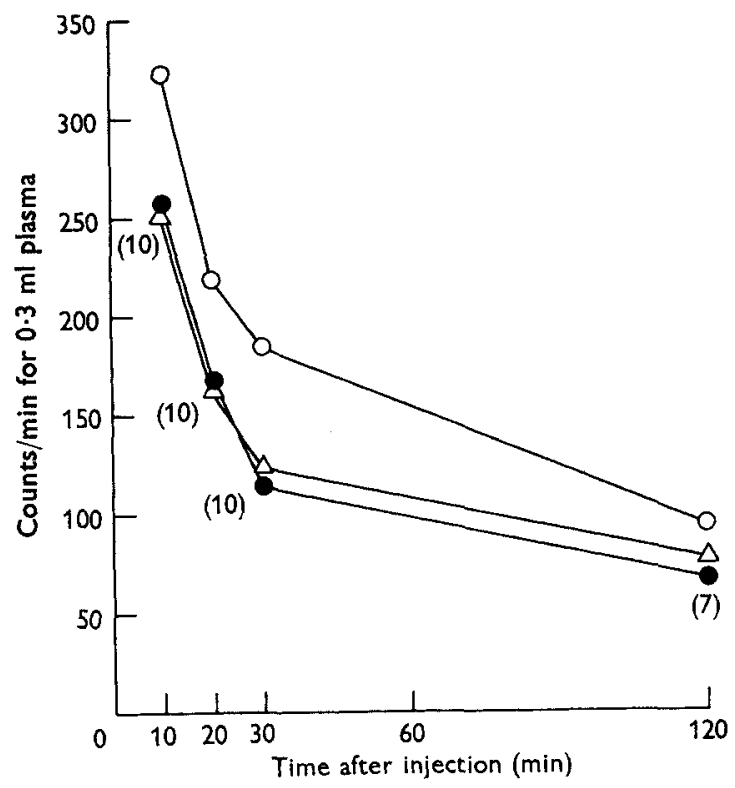

Fig. 2. Levels of ${ }^{45} \mathrm{Ca}$ in plasma of normal and rachitic chicks given ${ }^{46} \mathrm{CaCl}_{2}$ intravenously. Figures in parentheses are the number of chicks represented by each point. $0-0$, basal diet +23 i.u. vitamin $\mathrm{D}_{3} / \mathrm{r} 00 \mathrm{~g} ;-\longrightarrow$, basal diet; $\triangle-\triangle$, basal diet + dried liver ( $\equiv 20 \mathrm{~g}$ raw liver/I00 g).

these values shows that in $2 \mathrm{~h}$ relatively less $\mathrm{Ca}$ was deposited in the bones of the normal birds than in those of either of the rachitic groups. There was no difference between the values for the negative controls and those for the birds given the rachitogenic factor. In the one experiment that was terminated after $30 \mathrm{~min}$ a similar difference in $\mathrm{Ca}$ deposition was observed, but on this occasion the value for the chicks given the basal diet alone was intermediate between that for the normal birds and that for those given the rachitogenic factor.

From Fig. 2 it is apparent that the plasma radioactivity decreased more rapidly in the two groups of rachitic birds than in those with adequate vitamin $\mathrm{D}_{3}$. This finding 
is in accord with that of a greater deposition of ${ }^{45} \mathrm{Ca}$ in the bones, but might also be the result of a higher rate of excretion of ${ }^{45} \mathrm{Ca}$ by the rachitic birds. To test the latter possibility, groups of four normal and four rachitic chicks were each given intravenously I mg labelled $\mathrm{Ca}$ as chloride. The two groups were placed in cages with wire-screen floors, and their droppings were collected on filter-paper throughout $2 \mathrm{~h}$. The birds were then killed, and the kidneys and ureters from each group were combined with the droppings and ashed. The radioactivity was determined in a sample of calcium oxalate precipitated from the total ash, with the results:

\begin{tabular}{|c|c|c|c|}
\hline & $\begin{array}{l}\text { Total } \\
\text { weight of } \\
\text { oxalate } \\
\text { (g) }\end{array}$ & $\begin{array}{l}\text { Counts/min } \\
\text { at infinite } \\
\text { thickness }\end{array}$ & $\begin{array}{l}\text { Counts } / \mathrm{min} \\
\times \text { weight of } \\
\text { oxalate } \\
\text { (g) }\end{array}$ \\
\hline Normal birds & 0.2955 & 282 & $83 \cdot 3$ \\
\hline Deficient birds & 0.1489 & 449 & $66 \cdot 9$ \\
\hline
\end{tabular}

When adjustment is made for the difference in weight of ash from the two groups, it is clear that the deficient chicks excreted rather less ${ }^{45} \mathrm{Ca}$ than the normal ones. It can, therefore, safely be concluded that the more rapid disappearance of ${ }^{45} \mathrm{Ca}$ from the plasma of rachitic chicks was the result of a greater deposition in the skeleton. Except for the experiment lasting $30 \mathrm{~min}$, there was no observable difference between the groups given the rachitogenic factor and those given the basal diet alone, and on no occasion was there any indication that the rachitogenic factor interfered with deposition of ${ }^{45} \mathrm{Ca}$ in the bones.

\section{DISCUSSION}

In a previous paper Coates $\&$ Holdsworth (I96I) have shown that vitamin $D_{3}$ increased the rate at which rachitic birds absorbed $\mathrm{Ca}$ from a duodenal loop. The results obtained here confirm and extend these observations. Birds given a diet devoid of vitamin $\mathrm{D}_{3}$ for the first 4 weeks of life absorbed significantly less $\mathrm{Ca}$ than their hatchmates that had received ample vitamin $D_{3}$. When a supplement of dried pig'sliver was included in the rachitogenic diet, there was a strong indication that uptake of $\mathrm{Ca}$ was even further depressed, and this effect was observed whether the liver was given from hatching or only during the last 5 days of the 4 -week experiment. Although the apparent differences between uptake of $\mathrm{Ca}$ in birds receiving the liver and their corresponding controls were not statistically significant at the $P=0.05$ level, there is a strong suggestion that the rachitogenic properties of the pig's liver depend on its interference with absorption of $\mathrm{Ca}$ and that this effect can be reversed by small amounts of vitamin $\mathrm{D}_{3}$. A depressed absorption of $\mathrm{Ca}$ might occur if some reaction between the pig's liver and the $\mathrm{Ca}$ in the gut rendered the $\mathrm{Ca}$ less available to the animal. However, this explanation is unlikely, since the effect was obtained in washedout loops of intestine from which all but minute traces of food, and hence of the liver preparation, had been removed.

It has often been suggested that vitamin $D$ has a direct effect on the calcification of bone. That this is unlikely was shown by Migicovsky \& Emslie (I950) when they found similar amounts of ${ }^{45} \mathrm{Ca}$ deposited in bone after intramuscular injection of 
${ }^{45} \mathrm{CaCl}_{2}$ into both rachitic and normal chicks. Our results substantiate these findings, since by measuring the decrease in plasma ${ }^{45} \mathrm{Ca}$ with time after an intravenous injection of ${ }^{45} \mathrm{CaCl}_{2}$ the rate of removal of $\mathrm{Ca}$, presumably into the skeleton, could be followed. Rachitic chicks and rachitic chicks that had been given the rachitogenic liver extract both removed ${ }^{45} \mathrm{Ca}$ from the plasma more rapidly than did normal birds. It was shown that this was not due to more rapid excretion of ${ }^{45} \mathrm{Ca}$ and that the bones of the rachitic birds contained more ${ }^{45} \mathrm{Ca}$ than those of normal birds. It therefore appears that calcification of rachitic bone does not involve the direct effect of vitamin $\mathrm{D}_{3}$, although the reservation must be made that the rachitic chicks were probably not completely deficient of vitamin $\mathrm{D}_{3}$, and the minute amount of vitamin remaining might have had some function in calcification besides its primary effect on absorption. The rachitogenic factor also did not interfere with the ability of the bone to calcify, and it therefore seems that the rachitogenic effect of the pig's liver was due mainly to its effect on the mechanism of transport of $\mathrm{Ca}$ through the intestinal wall. Further investigation of this phenomenon awaits purification of the active material.

\section{SUMMARY}

I. The absorption of calcium was measured in tied-off duodenal loops in normal chicks and in chicks given a dietary supplement of pig's liver.

2. The pig's liver reduced the amount of $\mathrm{Ca}$ absorbed in both normal and rachitic chicks.

3. Deficiency of vitamin $\mathrm{D}_{3}$ in chicks did not interfere with the deposition in the skeleton of intravenously injected ${ }^{45} \mathrm{Ca}$.

4. In chicks given pig's liver the ability to deposit ${ }^{45} \mathrm{Ca}$ in the bone was similarly unimpaired. It is concluded that the rachitogenic effect of the pig's liver depended mainly on its interference with the uptake of $\mathrm{Ca}$ from the gut.

We are pleased to record our thanks to our colleague Dr R. F. Glascock for advice and assistance with the counting methods.

\section{REFERENCES}

Coates, M. E. \& Harrison, G. F. (1957). Proc. Nutr. Soc. I6, xxi.

Coates, M. E. \& Holdsworth, E. S. (1961). Brit. F. Nutr. I5, I31.

Migicovsky, B. B. \& Emslie, A. R. G. (1950). Arch. Biochem. 28, 324. 